\title{
Az idősödő társadalom gazdasági és társadalmi kihívásai Magyarországon
}

A cikk a TÁRKI Társadalomkutatási Intézet által végzett adatfelvételre támaszkodva elemzi az időskorú magyar lakosság aktivitásának mutatóit, és egy magyarázó modell segítségével vizsgálja bizonyos tényezők hatását az idős állampolgároknak az IKT eszközökhöz füződő viszonyára. Fő megállapítása, hogy az idősek fizikai, szellemi és társas aktivitása jelentősen befolyásolja az infokommunikációs eszközök iránti attitüdjük alakulását. Különösen erős a szellemi aktivitás hatása az IKT alkalmazására.

Kulcsszavak: idősek, aktivitás, egészség, tudás, IKT, Magyarország

\section{Szerzői információ:}

\section{Gyarmati Andrea}

szociológus jelenleg a Budapesti Corvinus Egyetemen folytat doktori tanulmányokat. Fóbb kutatási témái: a szociálpolitika és az informatika kapcsolata, közpolitikai hatáselemzések és ezek módszertana.

Így hivatkozzon erre a cikkre:

Gyarmati Andrea. „Az aktivitás szerepe az IKT időskori felhasználásában”.

Információs Társadalom IX, 4. szám (2009): 32-48.

$\mathbf{L}$

https://dx.doi.org/10.22503/inftars.IX.2009.4.2

A folyóiratban közölt müvek

a Creative Commons Nevezd meg! - Ne add el! - Így add tovább! 4.0

Nemzetközi Licenc feltételeinek megfelelóen használhatók. 
Gyarmati Andrea

\section{Az aktivitás szerepe az IKT idôskori felhasz nálásában}

\section{Kutatási cél és hipotézis}

A kutatás célja az 50 év fölötti magyar lakosság minél árnyaltabb jellemzése volt, az információs társadalomba való beilleszkedés szempontjából. Túllépve az idôsekról szóló diskurzus közhelyein, azokat a kulcstényezóket kerestük, melyek belülról szegmentálják ezt az igen nagy létszámú társadalmi csoportot, és akadályaivá válhatnak az idôsek információs társadalmi integrációjának. Feltételeztük, hogy ezeket a tényezôket azonosítva ajánlásokat tudunk megfogalmazni a döntéshozók számára.

Bár ismertek a demográfiai eloorejelzések és a világon számtalan vészforgatókönyv is készült, Magyarországon egyelôre igen kevés kutatás kínál kézzelfogható válaszokat vagy legalább új megoldási lehetôségeket a társadalom elöregedéséból fakadó kihívásokra, amelyek meglátásunk szerint egyszersmind egyéni, társadalmi és gazdasági lehetôségeket is hordoznak.

Kiindulási hipotézisünk az volt, hogy az idôsek korosztálya nem vagy csak nagyon nehezen szegmentálható a hagyományos szocio-demográfiai változók mentén, tehát a korosztály attitûdje és társadalmi cselekvése mögött új meghatározó tényezóket kell keresnünk. A nemzetközi szakirodalomban a WHO által bevezetett „aktív idôsödés” fogalma ${ }^{1}$ bizonyult számunkra a legjobban felhasználhatónak, mert megfelelő keretet biztosít egy magyarázó modell felállításához. Úgy véltük, hogy az idősek attitüdje - jelen esetben az IKT eszközökhöz való viszonyulása - mögött aktivitásuk különböző formáit kell keresnünk. Kutatásunkkal arra a kérdésre kerestük a választ, hogy az alábbiakban részletesen kifejtett fizikai, szellemi, társas és pszichés aktivitási formák közül melyik milyen mértékben befolyásolja az idôsek lépéstartását az információs és kommunikációs technológiák terjedésével.

\section{A minta általános leírása}

Az 50 év felettiek egészségi állapotára, munkavégzési és aktivitási hajlandóságára, társas kapcsolataira, infokommunikációs eszközökkel kapcsolatos attitúdjére és befekte-

1 Az active ageing angol kifejezés olyan társadalmi és egyéni gyakorlatot jelent, amellyel az idôskori életminôség javítható. Az aktív idősödés az egyén szintjén olyan időskor megélését fejezi ki, amely nem csupán gazdasági aktivitást, a munkaerôpiacon maradást jelent, hanem magában foglalja a társadalmi, kulturális és civil életben való aktív részvételt, a társadalmi reintegrálódást is. Mindehhez természetesen hozzátartozik egy olyan közpolitikai gyakorlat, mely megteremti az aktív idôsödés feltételeit, az életkor alapján történó diszkrimináció csökkentésétól kezdve a nyugdíjrendszer reformján át az intelligens otthonok nyújtotta szolgáltatásokig (WHO 2002). 
tési hajlandóságára vonatkozó kérdôíves felmérést a TÁRKI végezte el 2009 májusában és júniusában. A minta az 50 és 75 év közöttiek korosztályában nemre, korra, iskolai végzettségre, régióra és településtípusra nézve egyaránt reprezentatív, elemszáma 1003 fő.

A mintában szereplő 50 év felettiek 56\%-a nó, 44\%-a férfi. A megkérdezettek 68\%-ának életkora 50 és 65 év között van, a fennmaradó $32 \%$ kora 66 és 75 év közé esik. Átlagéletkoruk 61 év (férfiaknál 60, nóknél 61). 33\%-uk csupán legfeljebb 8 általános iskolai osztályt végzett, 31\%-uk valamilyen szakképzettséget szerzett érettségi nélkül, 20\%-uk érettségizett (ez utóbbiaknak majdnem a fele gimnáziumban). 11\%-uk rendelkezik felsőfokú végzettséggel. A fennmaradó 5\%-uk érettségi után akkreditált vagy nem akkreditált szakképzésben vett részt.

A megkérdezettek közel ötödrésze (18\%) él Budapesten. A Dél-Alföldi és az Észak-Alföldi régióban körülbelül 14-14\%-uk, Észak-Magyarországon 12\%-uk, a többi régióban (Közép-Magyarországon és a három dunántúli régióban) pedig 10-10\%-uk lakik. Településtípus szerint a legtöbben (33\%) községben, illetve városban (31\%) élnek (bár ez utóbbi, ismerve a hazai várossá nyilvánítási gyakorlatot, nem jelenti azt, hogy jobbak lennének az életkörülményeik, mint azoké, akik községben élnek). 18\%-uk valamelyik budapesti kerületben él, s ugyanennyien laknak a megyeszékhelyeken.

Családi állapotukról elmondható, hogy a többség házas és együtt él házastársával (53\%), mindössze 2\%-uk jelölte meg a „házas, de külön él” válaszlehetőséget. A megkérdezettek 25\%-a özvegy, 16\%-a elvált, míg 5\%-uk soha nem élt házasságban (nótlen vagy hajadon). Az együttélésre rákérdeztünk a háztartás nagysága szerint is: a válaszadók 28\%a él egyedül (ók felerészben özvegyek, harmadrészben elváltak, 10\%-uk pedig nótlen vagy hajadon). A kettesben együtt élók túlnyomó többsége (73\%) házas, 13\%-uk özvegy, $10 \%$-uk elvált, a többiek nótlenek vagy hajadonok. A hármasban vagy még nagyobb létszámú háztartásban együtt élók szintén nagyrészt házasok (72\%), s csak 1\%-uk él külön a házastársától. Az ilyen három vagy több fős háztartásokban éló idôs emberek 10-15\%-a özvegy vagy elvált. Ez utóbbi esetekben, vagyis amikor egyedülálló személy él több fôs háztartásban, következtethetünk a család szerkezetére is: feltehetóleg itt az egyik szüló él együtt valamelyik gyermekével és annak családjával (a családszociológiában az ilyen több családmagos típusokat nevezik összetett háztartásnak). ${ }^{2}$

Gazdasági aktivitás szerint a minta a következő megoszlást mutatja: 64\% nyugdíjas, $24 \%$ alkalmazott, $6 \%$ munkanélküli, $4 \%$ a saját vállalkozásában dolgozik, $1 \%$ alkalmi munkákból él, s további 1\% egyik kategóriába sem tudta besorolni magát.

\section{Egészség, jól-lét, függetlenség}

\section{A vizsgált dimenziók}

A megkérdezettek egészségi állapotának orvosi pontosságú felmérésére nem törekedhettünk, ugyanakkor fontosnak tartottuk azonosítani az egészségi állapotnak a jól-léttel kapcsolatos társadalmi dimenzióit, és igyekeztünk megvizsgálni a köztük lévố kapcsolatokat. Az egészségi állapotra közvetlenül és közvetve vonatkozó kérdések széles skálán mozogtak. Fớként az aktivitással kapcsolatban voltunk rá kíváncsiak (fizikai 
aktivitás, ezen belül munkavégzés és egyéb tevékenységek, szellemi aktivitás, szociális aktivitás, pszichés állapot), de rákérdeztünk az egészségi állapot szubjektív megítélésére is. Az egészségi állapotra utaló változókat aggregálva magyarázó változóként is felhasználtuk (az egészségi állapotot mérô változók hipotézisünk szerint egyrészt magyarázzák az aktivitás különbözố szintjeit, illetve korrelálnak ezekkel, másrészt befolyásolják az infokommunikációs eszközökhöz kapcsolódó attitû́döket).

A fizikai aktivitást jól mutatja a munkavégzés és az otthon vagy a lakóhely közelében végzett tevékenységek gyakorisága, az általános fizikai állapotot pedig bizonyos problémák (pl. érzékszervi, önellátással, mozgással kapcsolatos nehézségek) gyakoriságának, jellemzố voltának szubjektív megítélésével mértük.

A szellemi aktivitást három változó segítségével mértük, amelyeket részben korábbi kutatások (pl. Dombi 2008) tapasztalatait felhasználva választottunk ki. Ennél a korcsoportnál a szellemi aktivitás jó indikátora az újságolvasás, valamint a keresztrejtvényfejtés gyakorisága (ez utóbbit az idôsek a szórakozáson, idôtöltésen túl nagyon gyakran szellemi frissességük megórzésére is használják). A szellemi állapot szubjektív jelzốszáma a memória állapotára vonatkozott: a megkérdezettektól azt kértük, jelöljék meg egy ötfokú skálán, mennyire jellemzố rájuk, hogy gyakran elfelejtenek dolgokat.

A pszichés állapotra vonatkozóan a magány érzésével kapcsolatban tettünk fel két kérdést.

A szociális aktivitás dimenziójával, amely nagyrészt meghatározza a pszichés állapotot is, itt most csak jelzés-szerúen foglalkozunk, mivel a téma fontossága miatt külön tanulmányt szentelünk neki: ide tartozik a kapcsolatháló kiterjedése, az egymásnak segítés, a közösségekben való aktív részvétel és a bizalom témaköre is.

\section{A fizikai állapot szubjektív megitélése, az aktivitás fajtái és akadályai}

A fizikai állapot szubjektív megítélése kapcsán az érzékszervi problémákra, az orvosi rendelók látogatásának gyakoriságára, a közlekedésre és az önellátásra kérdeztünk rá egy egyszerú ötfokú skála segítségével. Mint ahogy az 1. ábrából is látszik, a közlekedés, a mozgás, a halkabb beszéd megértése és az önellátás a kérdezettek zömének nem okoz gondot. A vizsgált korcsoportra azonban jellemzô az orvosok gyakori felkeresése, és sokan említették a látással kapcsolatos problémáikat.

\section{Mennyire jellemzõk Önre az alábbi fizikai állapottal kapcsolatos problémák?}

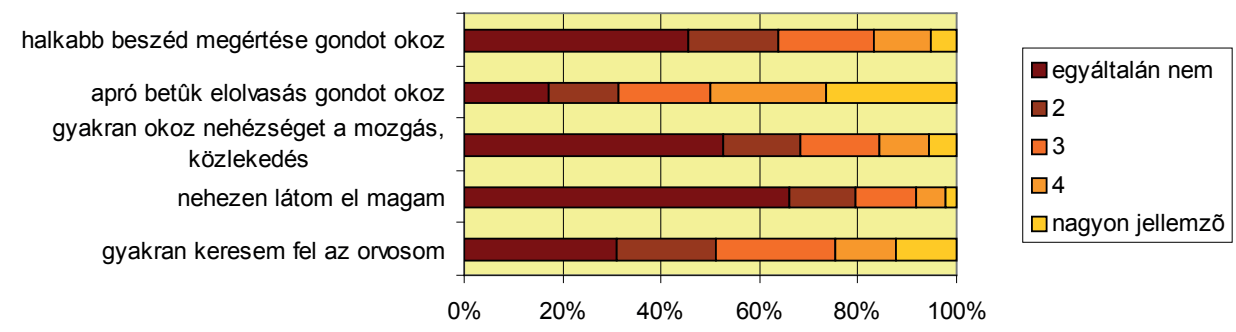

1. ábra

A fizikai állapot egyes összetevóinek megitélése 
A fizikai aktivitást nem könnyú, és nem is érdemes elválasztani a társas, illetve munka-jellegú aktivitástól: kutatási hipotézisünk szerint az aktivitás minden fajtája pozitívan hat az egészségre és az életminôségre. A 2. ábra oszlopdiagramjára pillantva megállapíthatjuk, hogy a leggyakoribb aktivitási forma a családtagoknak, szomszédoknak való segítés (80\%), de majdnem ennyire gyakori tevékenység a kertészkedés és a ház körüli munkavégzés (75\%) is. Gyerekekre, unokákra minden második 50 éven felüli idôs ember szokott rendszeresen vigyázni, a helyi szervezetek programjain való részvétel és a sport azonban jóval kevésbé népszerú elfoglaltság körükben. Az idősek ezek szerint a család aktív, segítô tagjai, akikre lehet számítani, ugyanakkor ez egyfajta bezártságot is eredményezhet.

\section{Szokott-e Ön rendszeresen...? (igen válaszok \%-os megoszlása)}

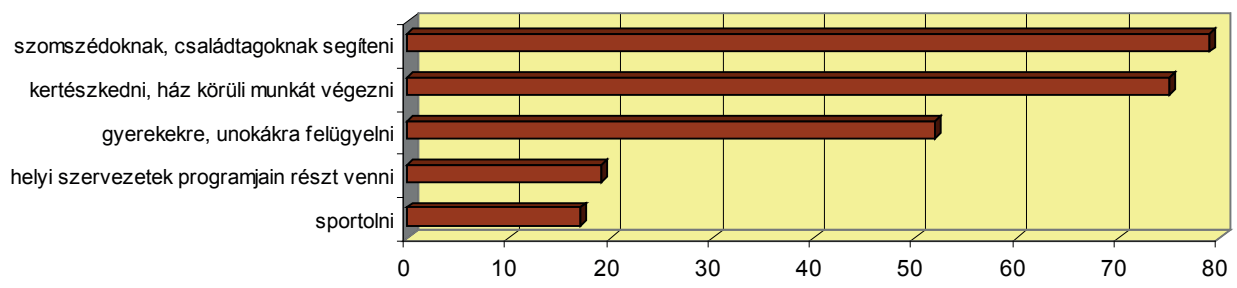

2. ábra

Rendszeresen végæett tevékenységek aะ 50 év feletti koros:tályban

A fizikai aktivitás különbözô formáira és a munkavégzésre vonatkozóan adott „igen” válaszokat összesítve, azt kapjuk, hogy az idôsek 5\%-a egyik aktivitási fajtát sem végzi rendszeresen, $12 \%$-uk végez egy tevékenységet, 25\%-uk kettốt, 30\%-uk hármat, 21\%-uk 4-et, 7\%-uk 5-öt, és 1,3\%-uk végzi rendszeresen az általunk felsorolt összes, vagyis 6 tevékenységet. Az így létrejöttegy egyszerú indexet kapunk, amelynek minél magasabb az értéke, annál aktívabb a megkérdezett személy.

\section{Szellemi aktivitás}

A szellemi aktivitást három változóval mértük: az újságolvasás és a keresztrejtvényfejtés gyakoriságával, valamint a memória múködésének szubjektív megítélésével. A megkérdezettek 13\%-a válaszolta, hogy soha nem olvas újságot, 12\%-uk nagyon ritkán, $21 \%$-uk alkalmanként, $17 \%$-uk gyakran, $37 \%$-uk pedig nagyon gyakran olvas. A rejtvényfejtés gyakorisága a kérdezettek többségére (44\%) egyáltalán nem jellemzó, 18\%-uk nagyon ritkán, $10 \%$-uk alkalmanként, $7 \%$-uk gyakran, $12 \%$-uk pedig nagyon gyakran fejt keresztrejtvényeket. A dolgok elfelejtése a válaszadók saját megítélése szerint 37\%-ukra egyáltalán nem jellemzô, 20\%-uknál nagyon ritkán, 24\%-uknál esetenként, 13\%-uknál gyakran fordul elő, és csak 5\%-uknál nagyon gyakori. A három változó közötti páronkénti korreláció szignifikáns, ${ }^{3}$ vagyis a három változó - hipotézisünket igazolva - megfelelő mó-

3 A felejtés és az újságolvasás gyakorisága között negatív, 0,01-es szinten szignifikáns kapcsolat áll fenn ( $\mathrm{PC}=-0,132)$, a felejtés és a rejtvényfejtés gyakorisága között szintén negatív, 0,05-ös szinten szigni- 
don írja le az idősek szellemi aktivitását. A változókat klaszteranalízis eljárás alá vonva a szellemi aktivitás mértéke alapján három csoportot tudtunk elkülöníteni:

1) A szellemileg aktívak csoportjára a gyakori újságolvasás, a gyakori keresztrejtvény-fejtés és a ritka memóriazavar jellemzố. Ôk a minta 28\%-át teszik ki.

2) A szellemileg passzívak gyakran elfelejtenek dolgokat, soha nem olvasnak újságot és soha nem fejtenek keresztrejtvényt. Ők alkotják a minta 32\% -át.

3) A minta 40\%-át a közepesen aktívak alkotják, akik ritkán felejtenek el dolgokat, gyakran olvasnak újságot, de ritkán fejtenek keresztrejtvényt.

1. tábla

Szellemi aktivitás klaszterek

\begin{tabular}{|c|c|c|c|c|}
\hline Klaszterek & Újságolvasás & Keresstrejtvény-fejtés & Memóriazavar & $N$ \\
\hline Szellemileg aktív & gyakran & gyakran & ritkán & 292 \\
\hline Közepesen aktív & gyakran & ritkán & ritkán & 389 \\
\hline Szellemileg passzív & soha & soha & gyakran & 315 \\
\hline
\end{tabular}

A három csoportot jellemezhetjük a szocio-demográfiai változók segítségével is, s így megtudhatjuk, hogy milyen társadalmi struktúra-képző változók (egyenlőtlenségi dimenziók) valószínüsíthetik, hogy valaki az egyik vagy másik csoportba kerül. Az iskolai végzettség alapján a kapcsolat szignifikáns és trend-jellegü: a 8 általánost vagy ennél kevesebb osztályt végzettek 46\%-a szellemileg passzív. A szakmunkás és szakközépiskolai végzettségüeknél már csupán 33\%, az érettségizetteknél 19\%, az érettségi után szerzett szakképzettséggel rendelkezőknél 23\%, míg a felsőfokú végzettségüeknél 20\%-os a szellemileg passzívak aránya. Az életkor összefüggése a szellemi aktivitással szintén szignifikáns: minél idősebb valaki, annál valószínűbb, hogy szellemileg passzív (az 50-65 éves kategóriában a passzívak aránya $29 \%$, míg a 66-75 éveseknél ez az arány $40 \%$ ). Ugyanakkor fontos hangsúlyozni, hogy még a 66 év felettiek körében is magasabb a szellemileg aktivak aránya, mint a passzivvaké. A háztartás lélekszámával szintén szignifikáns az összefüggés: minél népesebb háztartásban él egy idős ember, annál kevésbé valószínü, hogy a szellemi passzivitás lesz rá jellemző. Nemek szerinti bontásban gyengébb, de statisztikailag így is szignifikáns összefüggést találtunk: a szellemileg aktívak csoportján belül több a nő (31\%), mint a férfi (24\%), a passzívak csoportjában nincs eltérés, míg a közepesen aktívaknál a férfiak aránya magasabb (44\%, szemben a nők 36\%-ával). Településtípusok szerint - várakozásainktól eltérően - nem mutatkozott szignifikáns eltérés, ugyanakkor egy halvány törés mégis kirajzolódik: a szellemileg aktívak aránya a budapesti kerületekben élők esetében magasabb (31\%), mint a községi lakosok esetében (24\%). A többi településtípusnál nem találtunk jelentős eltérést az egyes vizsgált csoportok között. Ez az eredmény megerösíti a korábbi, hasonló kutatások eredményeit. Egyre biztosabban jelenthetjük ki, hogy az idősek csoportját településtípus alapján nem lehet szegmentálni: a lakóhely típusa nem magyarázza az idösek közötti (szellemi és egyéb) aktivitásbeli eltéréseket.

A munkaerópiaci aktivitás tekintetében a várakozásainknak megfelelóen alakultak az adatok: a szellemileg passzívak csoportján belül fóként munkanélküliek (37\%) és nyugdíjasok (37\%) találhatók, míg a szellemileg aktívak nagyrészt alkalmazottak (29\%).

fikáns kapcsolatot találtunk ( $\mathrm{PC}=-0,79)$, míg a rejtvényfejtés és az újságolvasás gyakorisága között pozitív, 0,01-es szinten szignifikáns a kapcsolat $(\mathrm{PC}=0,216)$. 
Az alkalmi munkákból élók körében kiugróan magas a szellemileg passzívak aránya (66\%), meg kell azonban jegyezni, hogy kevesen kerültek ebbe a kategóriába, tehát nem vonhatunk le messzemenó következtetéseket. A szellemileg közepesen aktívak között az önálló vállalkozók szerepeltek a legnagyobb arányban (57\%-uk tartozott ide).

Mint a késóbbiekben látni fogjuk, a szellemi aktivitás mértékét mutató változó az IKT eszközökhöz való viszony magyarázatában is fontos szerepet játszik.

\section{Pszichés állapot}

Az idősek jól-létének központi eleme az elmagányosodás problémája, mivel ezzel összefüggésben megnố az időskori depresszió, súlyosabb esetben a demencia kialakulásának valószínúsége. A pszichés állapotra vonatkozóan a következố két kérdést tettük fel: 1) „Mennyire érzi jellemzónek, hogy gyakran érzi magát egyedül?”, 2) „Szokta-e úgy érezni, hogy nincs, akivel megvitassa a világ dolgait?”. A két változó között erôs és szignifikáns kapcsolatot találtunk. A kérdésekre adott válaszok szórásának magyarázatára kiemeltük az életkort, a háztartás nagyságát és a munkaerópiaci aktivitást. A 3. ábra tanúsága szerint az egyedüllét, a magány érzése sokkal jellemzóbb probléma az idôsek körében, mint az, hogy nincs kivel megvitatni a világ dolgait (több mint kétszer annyian (9\%) mondták, hogy a magány nagyon jellemzố rájuk, mint ahányan (4\%) a vitapartnert hiányolták.

\section{Mennyire érzi jellemzõnek Önre?}

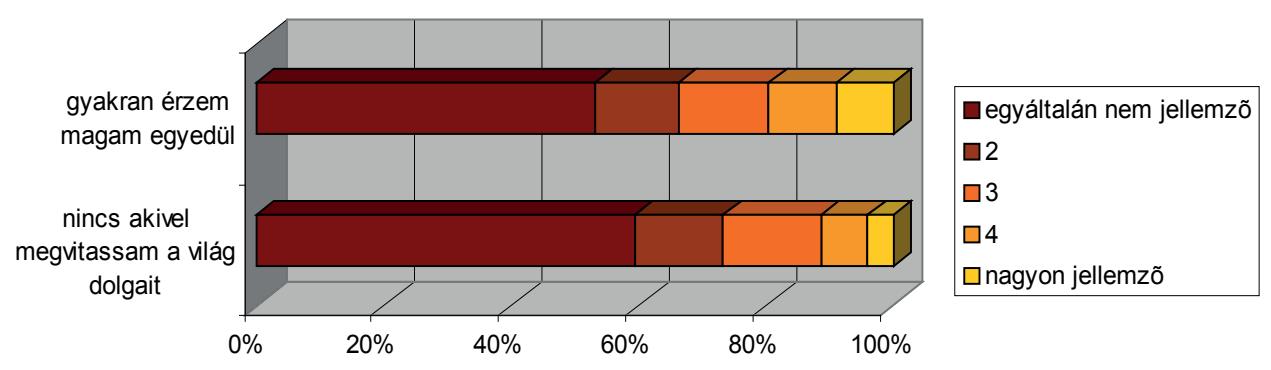

3. ábra

Az elmagányosodásra vonatkozó kérdésekre adott válaszok megoszlása

A két változó alapján elkülönítettük a „magányosak” és a „nem magányosak” csoportjait: az elóbbieket ( $\mathrm{N}=336)$ mindkét változó magas értékei jellemzik, míg az utóbbiaknál (N=664) ezek az értékek alacsonyak. A klaszterekból hierarchikus ANOVA eljárással modellt alkottunk, amelybe függó változóként (dummy változóként kezelve) magát a klasztert, magyarázó változóként pedig az életkort, a háztartás nagyságát és a munkaerópiaci aktivitást vontuk be. Az eredmények megfeleltek a várakozásainknak: mind a három változó szignifikánsan magyarázta a függó változó viselkedését (a köztük lévố interferencia nem szignifikáns, tehát egymással nem függ össze a három változó), a teljes megmagyarázott hányad azonban viszonylag kicsi, ${ }^{4}$ tehát más, itt nem elemzett

$4 \mathrm{R}^{2}=0,14$ 
tényezők is hatnak a magányosság-érzés kialakulására. A három változó közül legerősebb magyarázó ereje a háztartás nagyságának van, ezt követi a munkaerőpiaci aktivitás, valamint az életkor. Az átlagértékek megerősítik azt a közkeletű vélekedést, hogy minél idősebb valaki és minél kevesebb főből álló háztartásban él, annál inkább magányosnak érzi magát, a magány a fizikai egyedüllétből fakad. A munkaerőpiaci aktivitás szerint is van különbség: leginkább a munkanélküliek (és az alkalmi munkákból élők), legkevésbé pedig az alkalmazottak és az önállóak érezték magányosnak magukat.

2. tábla.

Társadalmi csoportok aะ érzett magányosság mértéke szerint

\begin{tabular}{|l|l|c|c|c|}
\hline \multirow{2}{*}{$\begin{array}{l}\text { Csoportképzóltozók } \\
\text { ván }\end{array}$} & Csoportok & $N$ & Átlagok & $\begin{array}{c}\text { Fóátlagtól való } \\
\text { eltérés }\end{array}$ \\
\hline \multirow{3}{*}{ Kor } & $50-65$ éves & 680 & 1,31 & $-0,03$ \\
\cline { 2 - 5 } & 65-70 éves & 315 & 1,41 & 0,06 \\
\hline \multirow{3}{*}{$\begin{array}{l}\text { A háztartás } \\
\text { nagysága }\end{array}$} & egyedül él & 280 & 1,57 & 0,22 \\
\cline { 2 - 5 } & ketten élnek együtt & 415 & 1,26 & $-0,08$ \\
\cline { 2 - 5 } & hárman vagy többen élnek együtt & 301 & 1,24 & $-0,09$ \\
\hline \multirow{4}{*}{$\begin{array}{l}\text { Munkaerópiaci } \\
\text { aktivitás }\end{array}$} & alkalmazott & 242 & 1,22 & $-0,11$ \\
\cline { 2 - 5 } & önálló, vállalkozó & 36 & 1,23 & $-0,10$ \\
\cline { 2 - 5 } & alkalmi munkákból, megbízásokból él & 9 & 1,71 & 0,37 \\
\cline { 2 - 5 } & munkanélküli & 57 & 1,44 & 0,10 \\
\cline { 2 - 5 } & nyugdíjas & 640 & 1,38 & 0,03 \\
\cline { 2 - 5 } & egyéb & 12 & 1,27 & $-0,06$ \\
\hline
\end{tabular}

Megjegyzés a 4. oszlophoz: a fơátlag értéke 1,34: minél nagyobb az eltérés ettól a pozitív irányban, annál erôsebb a magány érzése.

\section{Függetlenség, életminóség}

A függetlenség problémakörét három irányból közelítettük meg a kérdőívben. Meg akartuk tudni, hogy a megkérdezettnek van-e bármilyen fogyatékossága, betegsége, amely akadályozza a munkavégzésben és az otthoni teendók ellátásában, hiszen ez nagyban befolyásolja az életminóséget. Kíváncsiak voltunk továbbá a másoktól való függés mértékére bizonyos feladatok megoldásában, valamint arra is, hogy mit gondolnak az idôsek az állam gondoskodó szerepéról.

A megkérdezettek 35\%-a válaszolt igennel az így megfogalmazott kérdésre: „Van-e Önnek bármilyen fogyatékossága, krónikus betegsége?”. Tólük azt is megkérdeztük, hogy ez akadályozza-e óket egyrészt a munkavégzésben, másrészt az otthoni tevékenységekben. 47\%-uk jelezte, hogy a betegsége akadályozza a munkavégzésben, és mindössze 1 fő $(0,4 \%)$ említette az otthoni teendók ellátásának akadályozását. $A$ valamilyen fogyatékossággal vagy krónikus betegséggel éloók többségét (53\%) sem a munkavégæésben, sem a: otthoni feladatok ellátásában nem akadályoz:a a meglévó egéssségügyi problémája.

A megkérdezettek kétharmadára (66\%) egyáltalán nem jellemzó, hogy nehezen látja el magát, 26\%-uk néha , 8\%-uk pedig gyakran kerül ilyen helyzetbe. 96\%-uk szá- 
mára az volt a legfontosabb, hogy a saját megszokott környezetében élhessen, 4\%-uk esetében azonban az is felmerült alternatívaként, hogy idôsek otthonában vagy más, teljes ellátást biztosító gondozóhelyen éljenek. Ez azt jelzi, hogy a jelenlegi féróhelykapacitások jelentôsen elmaradnak a szükségletektól. A 2007. évi adatokat tartalmazó szociális statisztikai évkönyv (KSH 2008) szerint az 50 éven felüliek 3\%-a él idôsek otthonában. Ezt az adatot a kutatási eredményeinkkel összevetve megállapíthatjuk, hogy jelenleg az intézményen kívüli rászorulók körülbelül ugyanannyian lehetnek, mint a bent lakók. Ezzel azonban semmi esetre sem szeretnénk a nagyon drága állami féróhelyek számának növelése mellett érvelni, pusztán azt jelezzük, hogy a jelenlegi trendek mellett akkumulálódnak a kielégítetlen szükségletek, és szükség van ezek megfelelő kezelésére.

A többség nem várja el, hogy az állam gondoskodjon róla: 69\%-uk egyetértett azzal a kijelentéssel, hogy az idôseknek fel kell készülniük az önmagukról való gondoskodásra, és csupán 20\%-uk gondolta inkább azt, hogy az idôs, magatehetetlen emberekról való gondoskodás az állam feladata.

Egészségi állapotát a válaszadók 45\%-a összességében kielégítốnek tartja, többen tartják jónak (28\%), mint rossznak (21\%), és ugyanannyian minósítik kiválónak, mint nagyon rossznak $(3-3 \%)$.

\section{Összességében milyennek ítéli saját egészségi állapotát?}
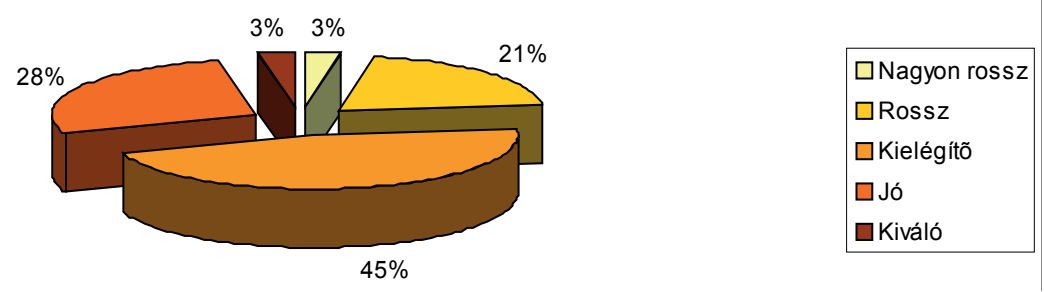

4. ábra

Az egészségi állapot szubjektí megitélése

\section{Infokommunikációs és egyéb eszközökkel támogatott egészségiiigyi szolgáltatások igénybevétele}

A függetlenség megórzése - mint a fentiekben is láthattuk - nagyon fontos az idôsek számára. Az Egyesült Államok és Japán trendjei arra mutatnak, hogy a függetlenség megórzésének egyre fontosabb eszközeit nyújtják a különbözô e-egészségügyi szolgáltatások, ezért különösen fontos figyelnünk erre a területre, annak ellenére is, hogy a magyar idôsek számára ezek nagy része ma még nem érhető el.

Ha nagyobb összeghez jutna, a kérdezettek mindössze 6\%-a költene egészségügyi szolgáltatásokra, illetve egészségének megớrzésére, javítására. Konkrét eszközöket említve azonban ennél jóval nagyobb meglévố szükségletek rajzolódnak ki. A legnagyobb érdeklődés az önkormányzatokon keresztül már ma is elérhetố ún. jelzốrendszeres házi segítségnyújtás szolgáltatás iránt mutatkozik, amelyet a megkérdezetteknek közel a fele „mindenképpen” vagy „talán” igénybe venne. Ennek az általában testre 
rögzíthetố eszköznek röviden az a funkciója, hogy a rajta lévó jelzố gombot aktiválva szükség esetén azonnal jön az orvosi segítség, így az idôs emberek állandó biztonságban érezhetik magukat a saját otthonukban is. Jól ismert lehetôség az otthonok akadálymentesítése is, ezt szintén sokan vennék igénybe (a megkérdezettek harmadrésze jelezte, hogy „mindenképpen” vagy „talán” igényt tartana rá). Az idôsek otthonainak akadálymentesítését szerény keretek között pályázati formában az állam is támogatja (legutóbb például a 2009 áprilisában zárult „Idősbarát” lakásprogram keretében 704 otthont akadálymentesítettek). ${ }^{5}$. A harmadik, szintén népszerü és szintén elérhető szolgáltatás az interneten való tájékozódás egészségügyi kérdésekben: ezt a válaszadók negyedrésze venné igénybe. A távdiagnózis, a receptek interneten keresztül történő felíratása és az intelligens otthon nyújtotta szolgáltatások azonban nem tartoznak a mindennapi magyar realitások közé, még a hallomás szintjén sem, s ennek megfelelően igény is kisebb mértékben mutatkozik irántuk (a megkérdezettek nagyjából ötödrésze azonban igényelné ezeket, ha lehetősége nyílna rá: érdekes, hogy leginkább a távdiagnózisra tartanának igényt). Úgy tünik tehát, hogy a lehetőségek nagyban meghatározzák a szükségleteket: minél ismertebb, minél több ember számára elérhető egy egészségügyi szolgáltatás, annál nagyobb iránta a kereslet is. Az adatok azt mutatják, hogy bár a korosztály egészségtudatossága nem kielégitö mértékü, az idősek nem kezelik vagyonként saját egészségüket (aminek prognosztizálható következménye az állami egészségügyi kiadások folyamatos, egyre gyorsuló ütemü növekedése), mégis reménykeltő, hogy konkrét funkciókat betöltö, jól müködö, innovatív eszközökre mutatkozik igény. Ezek elérhetővé válása nemcsak az egyének életminőségében okozhat javulást, hanem lehetővé teszi az állami kiadások szinten tartását is (erre konkrét példa a brit idősellátás reformjának hatáselemzése). ${ }^{6}$

\section{Igénybe venné-e az alábbi egészségüggyel kapcsolatos szolgáltatásokat?}

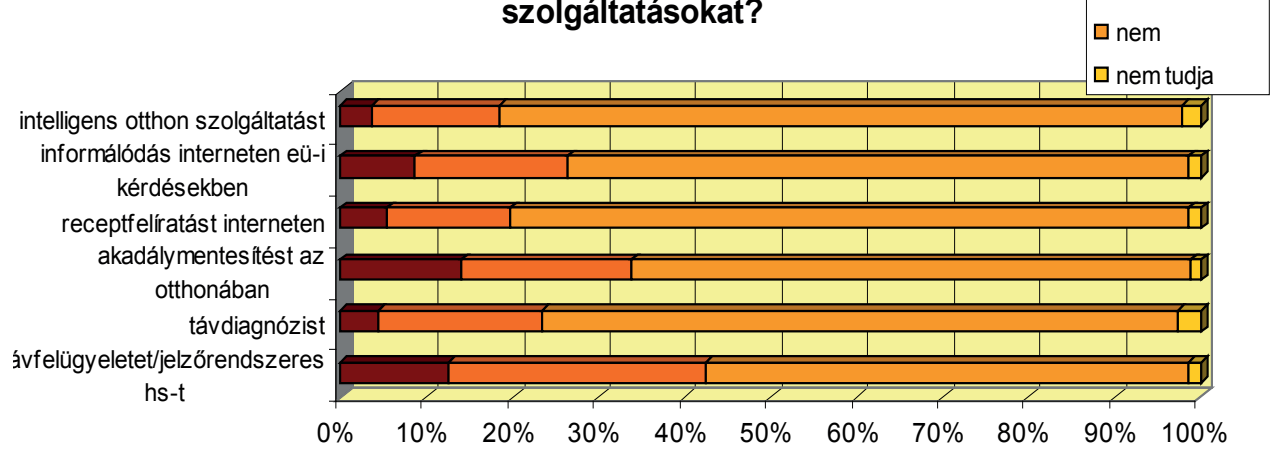

5. ábra

Egészségügyi szolgáltatások igénybevétele

5 http://www.szmm.gov.hu/main.php?folderID=16393\&articleID=41250\&ctag=articlelist\&iid=1

6 Lásd The state of social care in England: 2007-2008 címú jelentést, itt: http://www.cqc.org.uk/_db/_ documents/SOSC_07-08_easyread_web.pdf 


\section{Gazdasági aktivitás és inaktivitás, anyagi jólét}

\section{Az inaktivitás mértéke és okai}

Egy friss tanulmány (Tóth István György 2008) szerint, amely az Európai Unió társadalmainak elöregedési folyamatát és ennek következményeit mutatja be, a népesség öregedésének kedvezótlen munkaerôpiaci hatásaival várhatóan 2018-tól szembesülnek majd az EU tagországai. A munkaképes korú népesség csökkenése már ennél korábban, a baby boom nemzedék nyugdíjba vonulásával (nagyjából 2010-tól) megkezdôdik. Ennek a hatását azonban legalább idólegesen ellensúlyozni fogja a foglalkoztatottság növekedése, amit két tényezố magyaráz: nagyobbik részben a nók foglalkoztatása, kisebb részben pedig az idôskorúak foglalkoztatottságának bôvüló tendenciája. Az EU-25 országainak foglalkoztatási rátája az elôrejelzések szerint 2004 és 2010 között 63 százalékról 67 százalékra, 2020-ig pedig 70 százalékra nô. Így az EU 2020-ban éri el a Lisszaboni Szerző́désben elóirányzott foglalkoztatási rátát. Ezt követôen azonban a népesség öregedésének hatása fog dominálni, a foglalkoztatás összességében hanyatlásnak indul. Az Európai Bizottság prognózisa szerint a 2017-tốl 2050-ig tartó idôszakban a foglalkoztatottak összlétszáma hozzávetốlegesen 30 millió fơvel kevesebb lesz.

Magyarországon az idôsek foglalkoztatásának 1996 óta bơvüilő tendenciája 2008ban megtört. A KSH adatai szerint a dolgozó 50-59 éves korcsoport létszáma 2006ig folyamatosan emelkedett, 2007-ben stagnált, majd 2008-tól - feltehetóleg a válság következtében - csökkenni kezdett. Összességében így az 50-75 éves korosztálynak csak a negyedrésze (25\%) nevezhetố gazdaságilag aktívnak (szemben az EU 50\%-os átlagával).

50-75 éves gazdaságilag aktívak számának változása (ezer fö)

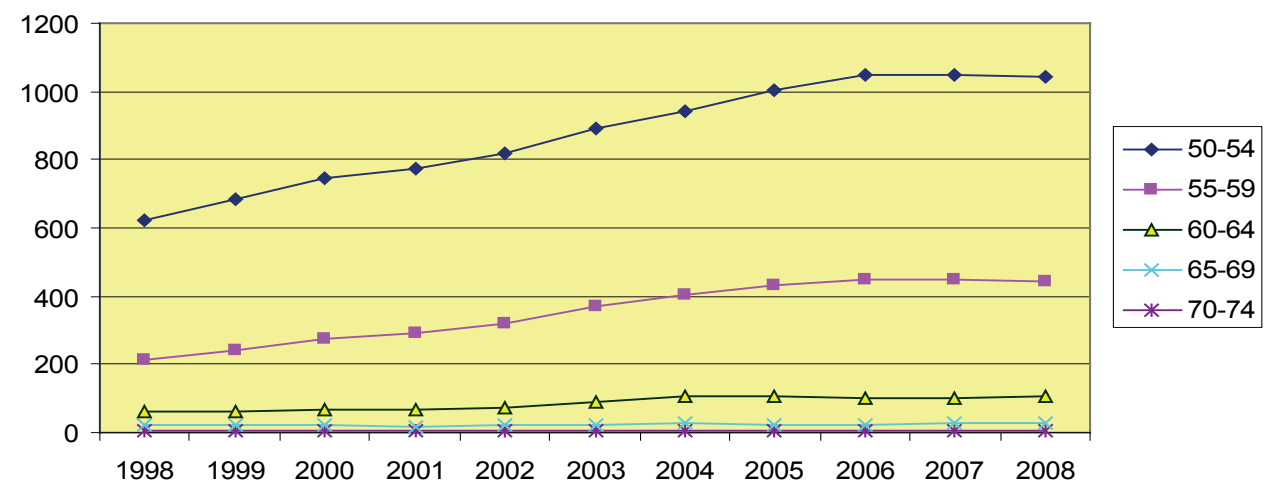

6. ábra

A gazdaságilag aktíuak számának változása korcsoportok szerint. Forrás: KSH, STADAT 2.1.12. tábla. A gazdaságilag aktívak sæáma korcsoportok szerint (1998-)

Az általunk megkérdezett inaktívak közül nyugdíjazásuk elốt a legtöbben (34\%) szakmunkásként dolgoztak, 20\%-uk betanított munkás, 13\%-uk diplomához nem kötött szellemi foglalkozású, 9\%-uk pedig segédmunkás volt, 6\%-uk végzett diplomához 
kötött tevékenységet, és 5\%-uk mezógazdasági fizikai dolgozóként hagyta el a munkaerópiacot. (A többiek valamilyen szintû vezetók voltak, s akadtak közöttük ôstermelók és olyan személyek is, akik sohasem dolgoztak).

Az inaktivitást legtöbben a nyugdíjas státuszukkal magyarázták: 43\%-uk azért nem dolgozik, mert „nyugdíjas és elegendő a jövedelme”. Ezt követi gyakoriságban az egészségi állapotra való hivatkozás (32\%), az idôsekkel szembeni diszkrimináció (20\%), továbbá az inaktívak 15\%-a szerint a lakóhelyén nincs munkalehetôség vagy csak kevés van, $13 \%$-uk pedig saját bevallása szerint azért tétlen, mert már egyáltalán nem szeretne semmiféle munkahelyen dolgozni. 6\%-uk jelölte meg inaktivitása okaként azt, hogy családi kötelezettségei miatt nem tud munkát vállalni.

\section{Ön jelenleg miért nem dolgozik? (igen válaszok\%-os megoszlása)}

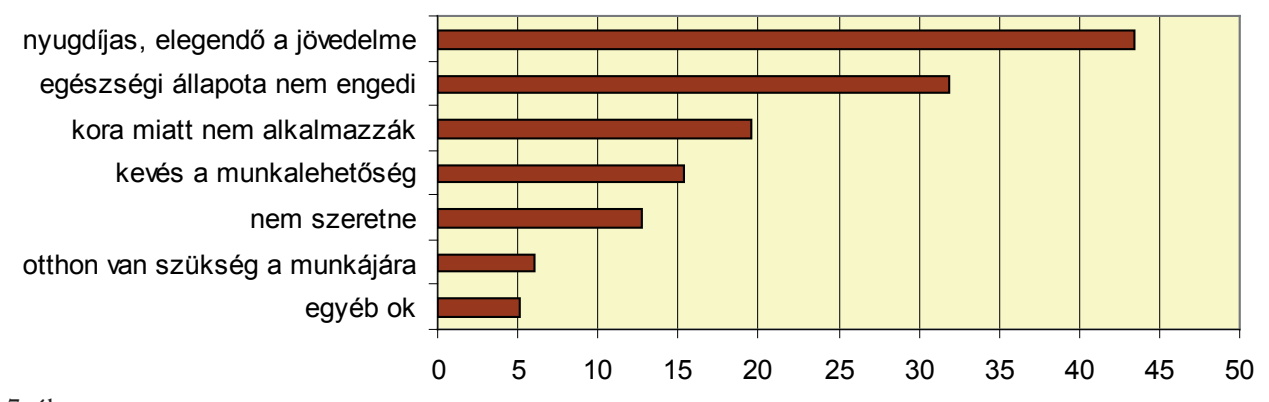

7. ábra

Az inaktivitás indokai

Megjegyzés: több válasz is megjelölhetố volt, a táblázat csak az igen válaszok \%-os arányát mutatja be.

\section{Aktivitásra össtönzớ tényezók}

A kérdezettek 35\%-a vállalna munkát, ha a szakmájában dolgozhatna. Ezen belül a részmunkaidô, annak is a 4 órás változata a legnépszerúbb (40\%-uk jelölte meg, hogy ennyit hajlandó lenne dolgozni), de majdnem ugyanennyien (37\%) választanák a teljes állást is. Mindössze 23\%-uk dolgozna napi 4-6 órás munkaidóben. Az összes válaszadó $17 \%$-a akkor is elfogadná a felajánlott munkalehetôséget, ha az nem felelne meg a szakmai képzettségének.

A tanfolyamok mint motivációs eszközök nem népszerúek: a megkérdezettek 80\%-a semmiképpen sem venne részt azért tanfolyamon, hogy újra dolgozhasson. $19 \%$-uk csak abban az esetben vállalkozna erre, ha a tanfolyam ingyenes lenne, és mindössze $2 \%$-uk lenne hajlandó fizetni is érte. Az utazás szintén erôs visszatartó erô: a válaszadóknak mindössze 3\%-a vállalna újra munkát, ha ingáznia kellene, a túlórázás azonban kevesebbeknek okozna problémát (ennek az elfogadottsága 17\%-os). Távmunkában az összes megkérdezett 9\%-a dolgozna újra, ha ilyen lehetôséget kapna, bedolgozóként viszont már 20\%-uk vállalna munkát. 14\%-ukat az motiválná egy munkalehetôség elfogadására, ha a családi kötelezettségekben segítséget kaphatna. Öszszefoglalva: a munkaerópiaci reintegráció legerösebb motiváló tényezóinek a saját ssakmához kapcsolódó esetleges munkalehetóség, illetve as atipikus foglalkoztatási formák bizonyultak: a 
részmunkaidó, bedolgozás, távmunka, de a család és munka összehangolásának lehetósége, illetve az ingázás elriasztó volta is ezeket a formákat jelöli ki elsốsorban a dolgozni képes/hajlandó idôsek számára.

\section{A tudás megszerzése és átadása}

Az idôsek felnốttkori tanulását (szélesebb értelemben a felnóttoktatásba való bevonását) és ennek állami támogatását az Unió 2001 óta szorgalmazza, egyrészt a demográfiai öregedés negatív hatásainak csökkentése céljából (hogy az idôsek tovább maradhassanak a munkaerópiacon, ami fokozza a versenyképességet), másrészt az életminôség javítása érdekében (hogy az idôsek ne szoruljanak ki a társadalomból és legyen terük a személyes továbbfejlődéshez). ${ }^{7}$

Varga (2006) a KSH felmérésére hivatkozva rámutat, hogy az EU 25 országai között a 24-64 éves korcsoportban Magyarországon a legalacsonyabb a felnóttkori tanulásban résztvevók aránya (12\%, szemben az EU 42\%-os átlagával), ráadásul 2003 óta csökkenó trend mellett. ${ }^{8}$

Ezek az arányok és trendek határozzák meg a vizsgált célcsoportnak a tudáshoz, illetve annak megszerzéséhez való negatív viszonyulását is, ami ugyanakkor közgazdaságtani értelemben nagyon is racionális viselkedés egy fóként inaktív keresókból álló csoport tagjainál, akiknek nagyon csekély az esélyük és a motivációjuk a munkaerópiaci reintegrációra. A megkérdezettek 37\%-a soha nem vett rész a szakmájához kapcsolódó továbbképzésben, s közel 50\%-uknak 3 évnél régebben volt erre legutóbb alkalmuk. Ez annyit jelent, hogy 87\%-uknak a tudása a munkaadói oldalról nézve egyáltalán nem nevezhetố naprakésznek, de a jelenlegi munkaerópiaci viszonyok között nem is túnne ésszerúnek a tudásuk naprakészen tartása. Csupán 7\%-uk vett részt ilyen tanfolyamon 1-3 éven belül, 4\%-uknak 1 éven belül, 3\%-uknak pedig az elmúlt 3 hónap folyamán volt erre lehetốsége. Más, nem a szakmához kapcsolódó tanfolyamokkal sem jobb a helyzet: a megkérdezettek mindössze 6\%-a vett részt az elmúlt évben ilyen képzésen, akár csak hobbiból. Ennek konkrét okaira a kérdóóivünk nem kérdezett rá, így csak feltételezhetjük, hogy ebben szerepet játszik egyfajta kognitív zártság, az új dolgok elutasítása, továbbá hozzáférési problémák merülhetnek fel (nem tudnak a tanfolyamokról, nem szerveznek számukra megfeleloót, nem tudnak eljutni a helyszínre stb.). Gyanítható, hogy sokan az önképzést vagy az informális tanulást részesítik elónyben a tanfolyamokkal szemben, s emellett arra is gondolhatunk, hogy ennél a korosztálynál már hiányzik az a munkaerópiaci kényszer, amely - mint számos korábbi kutatás (pl. Török 2006) bizonyítja - a felnótt magyar népesség tanulási hajlandóságának elsôdleges motiváló tényezóje.

7 Az Európai Unió Bizottságának „Az egész életen át tartó tanulás európai térségének valóra váltása” címmel 2001-ben kiadott közleménye és a Tanács által 2002-ben „Az élethosszig tartó tanulásról” hozott határozata is hangsúlyozza, hogy az élethosszig tartó tanulás nem csupán a versenyképesség és a foglalkoztathatóság, hanem a társadalmi felzárkóztatás, az aktív állampolgárság és a személyes fejlődés szempontjából is elengedhetetlen.

8 Vö. Eurostat: Labour Force Statistics, www.terport.hu 
Szakmai tanácsot a megkérdezettek 52\%-ától senki sem kért az elmúlt egy év során, 25\%-uknál ez kevesebb mint havi egy alkalommal fordult eló, és havonta több alkalommal, illetve heti gyakorisággal csupán 12, illetve 11\%-uknál történt meg. Nemcsak a tudás megszerzése, hanem a tudás átadása terén is problémákat azonosithatunk.

A saját tudásukról mindezek ellenére is pozitívan nyilatkoztak a megkérdezettek: mindössze 25\%-uk értett egyet azzal a kijelentéssel, miszerint „már rég elavult a tudása”, és 42\%-uk mondta azt, hogy „próbálja követni a változásokat” (8. ábra).

\section{Mennyire érzi tudását naprakésznek?}

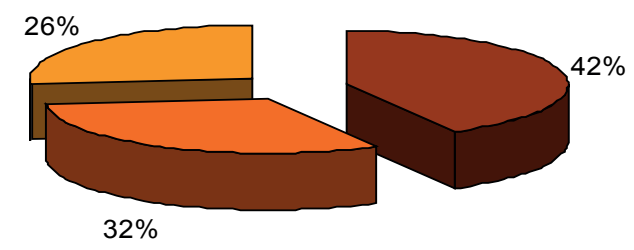

Próbálja követni a változásokat, a fejlödést

$\square$ Úgy érzi, egyre inkább elavult a tudása

$\square$ Már rég elavult a tudása

8. ábra

A tudás naprakészségének megitélése

Látható tehát, hogy az idôsek körében a saját tudásuk pozití megitélése és a tudásuk fejlesztésébe való csekély invesztálási hajlandóság voltaképpen öss:hangban áll egymással. Ezt támasztják alá az arra a kérdésünkre kapott válaszok is, amelynél a megkérdezetteknek állást kellett foglalniuk a következó, egymásnak ellentmondó kijelentésekkel kapcsolatban: 1) „a vállalatok rengeteget veszítenek azzal, hogy nem támaszkodnak az idősebb szakemberek tapasztalataira”, 2) „,az idôsek tudása már régen elavult”. A 9. ábra jól mutatja, hogy az idôsek döntố többsége (77\%) inkább azzal értett egyet, hogy az idős munkavállalók tudásának nélkülözése alig pótolható veszteséget okoz a vállalatoknak.

Mennyire ért egyet az alábbi kijelentésekkel? (\%)

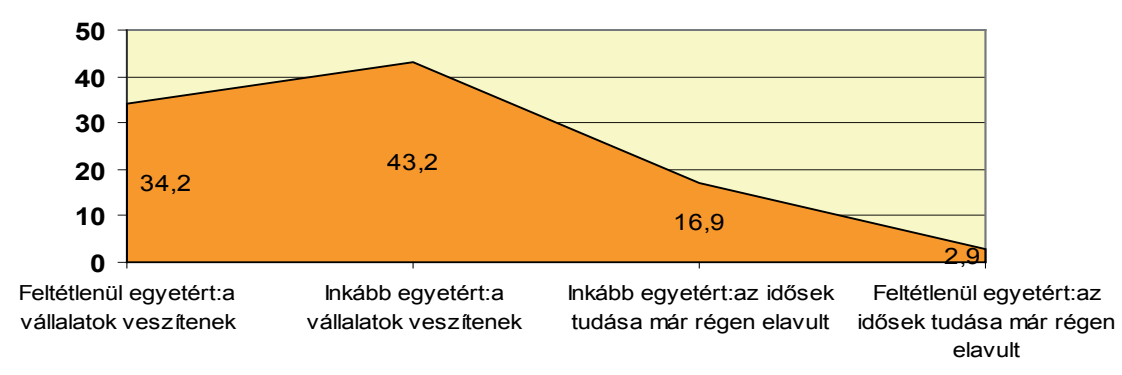

9. ábra

Hogyan itélik meg a idósek a saját tudásukat? 


\section{Anyagi helyzet}

A KSH egyik, az idôsek jövedelmi helyzetéról szóló tanulmánya (S. Molnár 2004) megállapítja, hogy az idôs népesség jövedelmei erôsen „középre húznak”, más szóval az idôsek körében az országosan jellemzốnél kisebbek a jövedelmi egyenlőtlenségek. Újabb adatok (Tóth István György 2006) ezt azzal egészítik ki, hogy a szegények aránya a 65 éven felüliek korcsoportjában a legalacsonyabb (az idôseknél 7\%, szemben például a 16-24 éves korosztály $17 \%$-os szegénységi rátájával). ${ }^{9}$

Jelen kutatásunk során az anyagi helyzetet a hagyományoknak megfelelően szubjektív és objektív indikátorokkal is mértük (az utóbbi esetben külön-külön véve figyelembe az egyén és a háztartás jövedelmét). Saját megítélése szerint a megkérdezettek $16 \%$-a küzd rendszeresen anyagi problémákkal, szintén 16\%-uknál gyakran, 25\%-uknál néha, 18\%-uknál pedig ritkán fordulnak elő megélhetési gondok, míg 25\%-ukra ez egyáltalán nem jellemző (10. ábra).

\section{Gyakran vannak anyagi problémáim: mennyire jellemzõ Önre?}

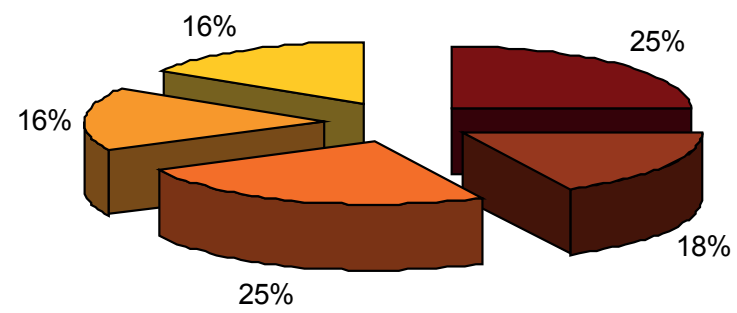

10. ábra

Az anyagi helyzet szubjektí megitélése

Az anyagi jólét szubjektív megítélését szignifikánsan magyarázza az iskolai végzettség szintje. Minél képzettebb valaki, annál kevésbé vannak anyagi gondjai: a csak általános iskolai vagy még alacsonyabb végzettségúek $28 \%$-ának vannak rendszeresen anyagi problémái, míg a felsốfokú végzettségúeknél ez az arány csak $5 \%$. A válaszadók életkorát és nemét tekintve az anyagi gondokkal nem találtunk összefüggést, a településtípus tekintetében azonban igen, de ebben az esetben pusztán arról van szó, hogy a Budapesten élók jövedelme azért magasabb, mert itt az iskolai végzettség átlagos szintje is az országos átlag felett van.

Személyes jövedelmét a megkérdezettek 70\%-a adta meg: ez igen magas aránynak tekinthetô. ${ }^{10} \mathrm{Az}$ átlagjövedelem 83 ezer forint. A kérdésre érdemi választ adók negyedrésze havi 56 ezer forint alatti jövedelemböl él., második negyedének jövedelme 57.000 és 73.000 Ft ezer forint közé esik, és körülbelül ugyanennyien gazdálkodhatnak ennél nagyobb összegekből. Megállapíthatjuk, hogy a jövedelmek között kicsi a szórás, az idősek a

9 A szegénységi küszöb itt a medián jövedelem 60\%-a.

10 A háztartások jövedelmének megadásánál már jelentôs volt a válaszmegtagadás, így ezeket az adatokat nem tudtuk érdemben elemezni. 
jövedelmi helyzetük szempontjából viszonylag homogén csoportot alkotnak. A jövedelem és az életkor között szignifikáns, de nem lineáris kapcsolatot találtunk: az 50-65 évesek nagy valószínűséggel a legalacsonyabb és a legmagasabb jövedelmi sávba kerülnek, míg a 66 évesek és ennél idősebbek jövedelme a közbülső második és a harmadik sávba (azaz 56 ezer és 91 ezer forint közé) esik. Hasonló összefüggés figyelhető meg a jövedelem és a nemi hovatartozás esetében is: a férfiakkal gyakrabban találkozunk a nagyon magas és a nagyon alacsony jövedelmi sávban, míg a nők jövedelme többnyire a két középső negyed valamelyikébe esik.

\section{A magyarázó modell}

A modell függó változóját az a kérdésünk adja, amellyel az IKT eszközök elfogadását, illetve elutasítását igyekeztünk mérni: „Ha megtehetné, vásárolna-e otthonába számítógépet, internetet?" A kérdésre kapott válaszok megoszlását a 11. ábra mutatja. Ebból kiderül, hogy az idôsek döntố többsége elutasító: azoknak az aránya, akik „nem látják értelmét” ezeknek az eszközöknek és akik „még ingyen sem” tartanának igényt ezekre, együttesen $80 \%$.

\section{Ha megtehetné, vásárolna-e otthonába számítógépet, internetet?}
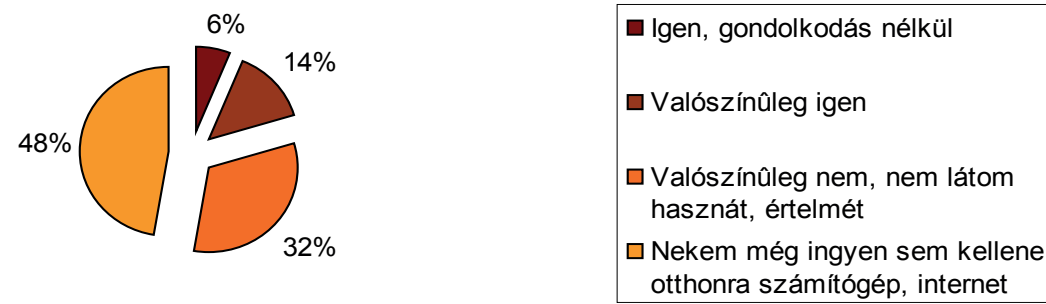

11. ábra

Venne-e számítógépet, internetet otthonra?

Miután sorra vettük azokat a tényezóket, amelyek befolyással lehetnek az idóseknek az internet és a számítógépek használatával kapcsolatos attitúdjére, befejezésként a következố megállapításokat tehetjük: Kiinduló hipotézisünk az volt, hogy az IKT elutasításának mértékét közvetlenül és közvetve (az aktivitásokon keresztül) is meghatározza az egészségi állapot. A regressziós modell lefuttatása ezt megerósítette: a modellben szereplő összes magyarázó változónak a függó változóra gyakorolt hatása szignifikáns. A függó változónk szórásának 12\%-át sikerült megmagyarázni. A regreszsziós Béta értékek értelmezéséból következik, hogy

1) minél alacsonyabb szintû́ a szellemi aktivitás, annál nagyobb mértékú az internet elutasítása;

2) minél kevésbé jellemzố valakire a társas aktivitás, annál valószínúbb, hogy elutasítja az internetet; 
3) minél intenzívebb a fizikai aktivitás (vagyis minél többféle tevékenységet végez valaki rendszeresen), annál kevésbé utasítja el az internetet; s végül

4) a magányosság érzése valóban fokozza az internet elutasítását.

A négy tényezố közül a szellemi aktivitás hatása a legerôsebb, ezt követi a társas aktivitás, a fizikai aktivitás, majd a pszichés állapot.

3. tábla

Regressziós modell

\begin{tabular}{|l|l|c|c|c|c|c|}
\hline \multirow{2}{*}{ Modell } & & \multicolumn{2}{|c|}{$\begin{array}{c}\text { Nem standardiæált } \\
\text { együtthatók }\end{array}$} & $\begin{array}{c}\text { Standardizált } \\
\text { egyïtthatók }\end{array}$ & $t$ & Sig. \\
\hline & B & $\begin{array}{c}\text { Standard } \\
\text { hiba }\end{array}$ & Beta & & \\
\hline 1 & (Konstans) & 2,325 &, 229 & & 10,157 &, 000 \\
\hline & társas aktivitás &, 258 &, 055 &, 178 & 4,676 &, 000 \\
\hline & szellemi aktivitás, &, 262 &, 044 &, 228 & 5,966 &, 000 \\
\hline & $\begin{array}{l}\text { fizikai aktivitás, te- } \\
\text { vékenységek száma }\end{array}$ &,- 067 &, 028 &,- 096 & $-2,443$ &, 015 \\
\hline & pszichés állapot &,- 159 &, 071 &,- 085 & $-2,234$ &, 026 \\
\hline
\end{tabular}

A függó változó: Ha megtehetné, vásárolna Ön otthonába számítógépet, internetet? $\mathrm{R}^{2}=0,12$

Az egészségi állapot szerepéról azt mondhatjuk, hogy minél jobb az egészségi állapot szubjektív megítélése, annál inkább csökken az internet elutasítása. Mint láttuk, az egészségi állapot nemcsak közvetlenül, hanem közvetve, a többi változón keresztül is kifejti hatását (legerôsebben a fizikai aktivitásra, másodsorban a pszichés állapotra, ezt követốen a társas aktivitásre, és a legkisebb mértékben a szellemi aktivitásra hat).

\section{Összefoglalás: problémák és ajánlások}

Az aktivitásra vonatkozó kezdeti hipotézisünk tesztelése nem várt eredményeket is hozott: úgy túnik, az idősek korosztályát elsôsorban a szellemi aktivitás alapján lehet szegmentálni, a szellemi aktivitás azonban az összes általunk vizsgált aktivitásfajta közül a legkevésbé függ az egészségi állapottól. Emellett a szellemi aktivitás befolyásolja a legnagyobb mértékben az IKT eszközök elfogadását, illetve elutasítását is. Úgy tünik, hogy az idôsek életminóségének, jól-létének kulcsa a szellemi aktivitás. Ajánlásként megfogalmazható, hogy olyan fejlesztési programokra volna szükség, amelyek elsôsorban ezt a területet érintik: itt sok mindenre gondolhatunk, a könyvtárak szolgáltatásaitól kezdve a memóriát tesztelô ún. komoly játékok hozzáférhetôvé tételéig.

Az idôsek egészségi állapota és munkavégzésre való alkalmassága a megkérdezettek szubjektív megítélése alapján kielégítónek mondható. Ugyanakkor jellemzố a korosztályra az orvosi vizsgálatok gyakori igénybevétele, s tagjainak egészségi problémái közül ki kell emelni a látással kapcsolatosakat. Tudatában kell lennünk annak, hogy a saját egészségük, tudásuk és aktivitásuk reális megítélése és tudatos kezelése, valamint az ezek megốrzésébe és fejlesztésébe való befektetésre való hajlandóság egyáltalán nem jellemzố a vizsgált korosztály tagjaira, viszont a függetlenségük megốrzése 
- akár IKT eszközök segítségével is - fontos számukra. A függetlenséget fokozó eszközök pozitív fogadtatását a példakövetés határozza meg: minél többen használnak egy eszközt, annál nagyobb lesz iránta a kereslet. Ezen a területen már rövidtávon is áttörés várható, még az állami kiadások szinten tartása vagy csökkentése mellett is.

Az idôseknek a munkaerôpiacra való visszatérését - mint láttuk - az atipikus munkavégzési formák terjedése és elérhetôvé válása segítheti elő: a részmunkaidô, a bedolgozás és a távmunka már természeténél fogva is kedvezô számukra, de a család és a munka összehangolásának lehetôsége, valamint az ingázás fáradalmaitól való idegenkedés is ezeket a formákat jelöli ki elsốsorban a dolgozni képes és hajlandó idôsek foglalkoztatásához. Az ilyen programoknak tehát az idôseket is meg kellene célozniuk.

A tudás megszerzését és átadását tekintve, az általunk feltárt és elemzett adatok, valamint a munkaerópiac jelenlegi tendenciái alapján úgy gondoljuk, hogy ennél a koros:tálynál a szakmai tudás tanfolyami keretek közötti frissitésének nincs sok értelme, ugyanakkor $a$ idoósek életminoóségét javító tanulás szorgalmasása, valamint as idoosek oktatóként való foglalkoztatása a felnóttoktatásban reális össztársadalmi hašonnal járhat.

\section{Irodalom}

Andorka Rudolf (1997): Bevezetés a szociológiába. Osiris kiadó, Budapest

Dombi Gábor - Molnár Szilárd - Kollányi Bence (2008): E-befogadás Magyarországon éves jelentés (2008) http://www.ittk.hu/web/docs/ebefogadas_eves_jelentes_2008. pdf letöltve: 2009.aug.10

S. Molnár Edit (2004): Az idôskorú népesség fóbb jellemzối és életkörülményei. KSH, Bp.

Szántó Zoltán (2006): Analitikus szemléletmódok a modern társadalomtudományban. Helikon kiadó, Bp.

Tóth István György (2006): Jövedelemeloszlás 1987 és 2005 között. In: Kolosi Tamás Tóth István György (szerk.) Társadalmi Riport, 2006. Tárki, Bp.

Tóth István György (2008) (szerk.): Tárki-Unicredit Európai Társadalmi jelentés, Budapest

Török Balázs (2006): Felnốttkori tanulás - célok és akadályok. Educatio 2006/2 pp. 333-347.

Varga Júlia (2006): Humántóke-fejlesztés, továbbtanulás felnôttkorban, szkillek és kompetenciák. In: Kolosi Tamás - Tóth István György (szerk.) Társadalmi Riport, 2006. Tárki, Bp.

WHO (2002): Active aging: A policy framework. http:/www.who.int/ageing/publications/ active/en/index.html Letöltve: 2009. aug. 10. 